\title{
Next-Generation COVID-19 Vaccines Should Take Efficiency of Distribution into Consideration
}

\author{
Khaled AboulFotouh, ${ }^{1,2}$ Zhengrong Cui, ${ }^{1,3}$ and Robert O. Williams III ${ }^{1,3}$ (D)
}

Received 25 October 2020; accepted 24 February 2021; published online 9 April 2021

Abstract. The dire need for safe and effective coronavirus disease (COVID-19) vaccines
is met with many vaccine candidates being evaluated in pre-clinical and clinical studies. The
COVID-19 vaccine candidates currently in phase 3 or phase $2 / 3$ clinical trials as well as those
that recently received emergency use authorization (EUA) from the United States Food and
Drug Administration (FDA) and/or other regulatory agencies worldwide require either cold
(i.e., $2-8^{\circ} \mathrm{C}$ ) or even freezing temperatures as low as $-70^{\circ} \mathrm{C}$ for storage and distribution.
Thus, existing cold chain will struggle to support both the standard national immunization
programs and COVID-19 vaccination. The requirement for cold chain is now a major
challenge towards worldwide rapid mass vaccination against COVID-19. In this commentary,
we stress that thermostabilizing technologies are available to enable cold chain-free vaccine
storage and distribution, as well as potential needle-free vaccination. Significant efforts on
thermostabilizing technologies must now be applied on next-generation COVID-19 vaccines
for more cost-effective worldwide mass vaccination and COVID-19 eradication.

KEY WORDS: SARS-CoV-2; Dry powder; Thermostability; Cold chain; Vaccine.

\section{INTRODUCTION}

The novel severe acute respiratory syndrome coronavirus 2 (SARS-CoV-2) is the etiological agent of COVID-19 that has been declared a pandemic by the World Health Organization (WHO) on March 11, 2020 (1,2). SARS-CoV-2 has a single-stranded positive-sense RNA genome that encodes structural proteins as well as nonstructural and accessory proteins $(3,4)$. The critical structural proteins are (i) spike (S) protein that mediates the entry of the virus into the host cells, (ii) nucleocapsid protein that protects the viral RNA against the surrounding host cells, (iii) membrane protein that enables the viral RNA to bind to the inner surface of the host cell membrane, and (iv) envelop protein (1).

The S glycoprotein has two functional subunits, namely, S1 that mediates cellular attachment and S2 that mediates viral and cellular membrane fusion (5). The S1 receptorbinding domain (RBD) mediates the binding of SARS-CoV-2 to the angiotensin-converting enzyme (ACE2) host cell receptor followed by viral internalization into the cells $(1,5)$. ACE2 receptor is expressed in many tissues in the body,

\footnotetext{
${ }^{1}$ Division of Molecular Pharmaceutics and Drug Delivery, College of Pharmacy, The University of Texas at Austin, Austin, Texas 78712, USA.

${ }^{2}$ Department of Pharmaceutics, Faculty of Pharmacy, Assiut University, Assiut, 71526, Egypt.

${ }^{3}$ To whom correspondence should be addressed. (e-mail: zhengrong.cui@austin.utexas.edubill.williams@austin.utexas.edu)
}

including type II pneumocytes (i.e., surface epithelial cells of the alveoli), enterocytes, and oral mucosal epithelium (6).

The leading cause of COVID-19 mortality was reported to be the acute respiratory distress syndrome, which is initiated by the infection of lung epithelium by SARS-CoV-2 viruses and the activation of alveolar macrophages (1). Immune-mediated cytokine storm and RNAemia also contribute to the severity of COVID-19 (6,7). As of January 31, 2021, the WHO official data showed 102,083,344 confirmed COVID-19 cases including 2,209,195 deaths (8). The transmission of SARS-CoV-2 from asymptomatic individuals is the main contributing factor to the large number of COVID-19 cases (3). Thus, the development of prophylactic vaccines is the key in stopping SARS-CoV-2 transmission and infection and ultimately eradicating COVID-19.

Many COVID-19 vaccine candidates are being evaluated in different phases of clinical trials and some have already been granted emergency use authorization (EUA). However, almost all these candidates require distribution and storage in either cold (i.e., $2-8^{\circ} \mathrm{C}$ ) or ultra-cold temperatures (i.e., $-20^{\circ} \mathrm{C}$ or $\left.-70^{\circ} \mathrm{C}\right)$. According to the WHO, vaccines should be stored in a system that maintains them in good condition. This system is referred to as the "cold chain" and is designated to keep vaccines within the WHO recommended temperature ranges (i.e., 2 to $8^{\circ} \mathrm{C}$ or -15 to $-25^{\circ} \mathrm{C}$ ). Astoundingly, cold chain accounts for $\sim 80 \%$ of the cost of vaccination programs in the developing countries (9). Cold chain failure can result in significant losses of vaccines that are considered lifesaving in the case of pandemics such as 
COVID-19. For instance, 1900 doses of the Moderna's COVID-19 vaccine were ruined when a freezer was accidentally unplugged at a Veteran's Hospital in Boston (10). Additionally, temperature-controlled supply chain is a major obstacle towards rapid and efficient distribution of vaccine.

In this commentary, we discuss various COVID-19 vaccine candidates that had received EUA or are in phase 3 or phase $2 / 3$ clinical trials with the main emphasis on their cold chain requirements and propose that vaccine developers and manufacturers must now consider the stability of their vaccine candidates at ambient temperatures or at least at cold temperatures (i.e., $2-8^{\circ} \mathrm{C}$ ) in order to achieve rapid and efficient vaccine distribution and thus mass vaccination without significantly compromising the existing national immunization programs. This can be achieved via the selection of the appropriate technology as well as the optimization of vaccine formulation.

\section{TUTORIAL ON COVID-19 VACCINES IN PHASE 3 OR PHASE 2/3 CLINICAL TRIALS, WITH OR WITHOUT EUA}

Vaccine design considers the selection of proper virusderived antigens, the vaccine technologies, and the route of administration (11). As of January 26, 2021, there were 63 COVID-19 vaccine candidates in clinical evaluation and an additional 173 in preclinical evaluation (12). A remarkable feature of the COVID-19 vaccine development landscape is the array of novel as well as traditional technology platforms being evaluated, including nucleic acid (i.e., mRNA and DNA), recombinant protein, viral vector, bacterial vector, live attenuated, virus-like particles (VLPs), and inactivated virus-based vaccines (13-15). The technology used to develop the vaccine determines the potency of vaccine antigens, the need for immune adjuvant, and the type of protective immunity induced (11). Table I summarizes various COVID-19 vaccine candidates in phase 3 or phase 2/3 clinical trials. According to the WHO, as of January 26, 2021, there were 22 vaccine candidates belonging to seven different platforms in phase 3 or phase $2 / 3$ clinical trials around the world (12).

\section{Adenovirus Vector-Based SARS-CoV-2 Vaccines}

AZD1222 (i.e., ChAdOx1-S) was developed by researchers at Oxford University and licensed by AstraZeneca (38). The results of phase $1 / 2$, single-blind, randomized, controlled clinical trial (i.e., NCT04324606) showed that AZD1222 was safe, well tolerated, and induced both cellular and humoral immune responses in all participants (39). The interim analysis of four clinical studies (i.e., two phase $1 / 2$ studies in South Africa (i.e., NCT04444674) and United Kingdom (UK) (i.e., NCT04324606), a phase $2 / 3$ study in UK (i.e., NCT04400838), and a phase 3 study in Brazil (i.e., ISRCTN89951424)) showed an efficacy of $70.4 \%$ (40). On December 30, 2020, the UK Medicines and Healthcare Products Regulatory Agency (MHRA) granted EUA for ADZ1222 vaccine. The vaccine is currently authorized for use in the UK and many other countries worldwide (41).

Ad26.CoV2.S, Janssen's COVID-19 vaccine, is Ad26 vector-based, and CanSinoBio's COVID-19 vaccine is Ad5 vector-based $(42,43)$. Sputnik V, the vaccine candidate developed by the Gamaleya Research Institute of Epidemiology and Microbiology, is unique in that it is based on Ad5 and Ad26 for heterologous priming and boosting (17). It elicited strong humoral and cellular immune responses in phase $1 / 2$ clinical trials (i.e., NCT04437875 and NCT04436471) (17).

\section{Inactivated SARS-CoV-2-Based Vaccines}

CoronaVac is an inactivated SARS-CoV-2 vaccine candidate (27). CoronaVac provided either partial or complete protection against SARS-CoV-2 in rhesus macaques without eliciting antibody-dependent enhancement of virus infection (44), which was previously found in animals immunized with severe acute respiratory syndrome coronavirus (SARS-CoV) or Middle East respiratory syndrome coronavirus (MERS$\mathrm{CoV}$ ) vaccine candidates prepared with the inactivated whole virus or the full-length $\mathrm{S}$ proteins, respectively $(45,46)$. The results of phase $1 / 2$ clinical trial (i.e., NCT04352608) showed that CoronaVac is well tolerated and can induce SARS-CoV2-specific humoral immune responses in healthy adults (18-59 years of age). These findings supported the initiation of phase 3 clinical trial (i.e., NCT04582344).

Two other inactivated SARS-CoV-2 vaccine candidates currently in phase 3 clinical trials were developed by the Wuhan Institute of Biological Products and the Beijing Institute of Biological Products (i.e., BBIBP-CorV), independently, in coalition with Sinopharm $(12,28)$. The results of phase $1 / 2$ clinical trials showed that both vaccine candidates are well tolerated and can elicit humoral immune responses against SARS-CoV-2 rapidly in healthy adults $(47,48)$. All of them had been granted EUA in China and/or many other countries, and public availability of data from phase 3 clinical trials is pending (49).

Bharat Biotech, Indian Council of Medical Research, and the National Institute of Virology developed a wholevirion inactivated SARS-CoV-2 vaccine called COVAXINTM (also known as BBV152), which is also currently evaluated in a phase 3 clinical study (i.e., NCT04641481) (31). COVAXIN"M was granted "for restricted use in emergency situation in public interest as an abundant precaution, in clinical trial mode" in India on January 2, 2021 (50).

\section{SARS-CoV-2 mRNA Vaccines}

Another platform for the development of COVID-19 vaccine candidates is the mRNA. Messenger RNA can accelerate the development of COVID-19 vaccine because it combines the ease of manufacturing and efficient modification of the encoded antigen (51). Messenger RNA-based vaccines can induce strong immune responses by generating potent neutralizing antibodies and activating $\mathrm{CD}^{+}$and $\mathrm{CD}^{+} \mathrm{T}$ cells, while reducing the potential risks of infection and mutagenesis (52). Finally, mRNA vaccines can be potentially rapidly modified to address any new SARS-CoV-2 mutations $(53,54)$. Both Moderna's mRNA-1273 and Pfizer/BioNTech's BNT162b2 vaccine candidates were recently granted EUA by the FDA.

Moderna's mRNA-1273 vaccine is a lipid nanoparticleencapsulated mRNA (20). Encapsulation of the mRNA within the lipid nanoparticles provides the mRNA protection against enzymatic degradation, facilitates its uptake by target 


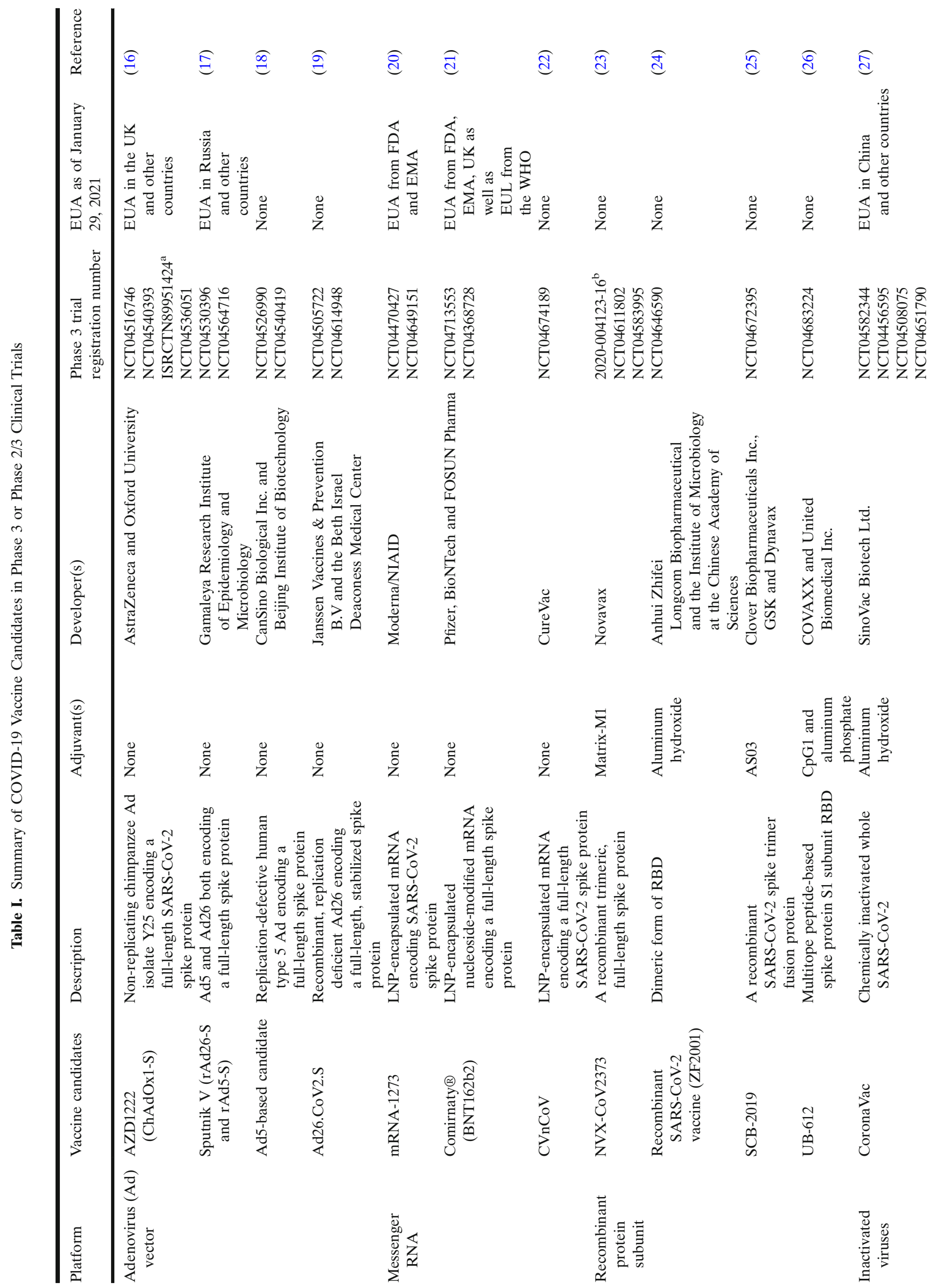


cells, and improves the immunogenicity (55). No trial-limiting safety concerns were reported during the phase 1, doseescalating, open-label clinical trial that involved the vaccination of healthy adults (18-55-year-old) with two doses (each $25 \mu \mathrm{g}, 100 \mu \mathrm{g}$, or $250 \mu \mathrm{g}) 28$ days apart; however, $21 \%$ of participants who received the $250 \mu \mathrm{g}$ dose showed one or more severe adverse events (20). This phase 1 clinical trial was expanded to test mRNA-1273 in older population (i.e., $56-70$ or $\geq 71$ years of age) at a dose of either $25 \mu \mathrm{g}$ or $100 \mu \mathrm{g}$ (56). Older population showed mild to moderate adverse events. The $100-\mu \mathrm{g}$ dose induced high binding and neutralizing antibody titers as compared to the $25-\mu \mathrm{g}$ dose, and thus, it was selected for further evaluation in a large phase 3 clinical trial (i.e., NCT04470427) (56). Subjects who received Moderna's mRNA-1273 vaccine retained high levels of neutralizing anti-SARS-CoV-2 antibodies for 119 days after the first vaccination. However, memory $B$ and $T$ cell responses to mRNA-1273 vaccine are not yet delineated (57). Moderna's mRNA-1273 vaccine received EUA from the FDA and the European Medicines Agency (EMA) on December 18, 2020, and January 6, 2021, respectively.

Pfizer and BioNTech launched their BNT162 (i.e., Comirnaty $\left.{ }^{\circledR}\right)$ mRNA-based vaccine candidate by comparing four vaccine candidates in an umbrella-type clinical trial to select a single vaccine candidate and dose level for a critical global safety and efficacy trial (21). Two vaccine candidates (i.e., BNT162b1 and BNT162b2) showed superior safety and immune responses. Both BNT162b1 and BNT162b2 are lipid nanoparticle-encapsulated nucleoside-modified mRNAs that encode trimerized SARS-CoV-2 RBD of the S glycoprotein and the full-length $S$ glycoprotein, respectively $(21,58)$. The preliminary results of phase $1 / 2$ clinical trial showed a favorable overall tolerability profile for the BNT162b2 in terms of less systemic reactogenicity, and it was thus selected for the large-scale phase $2 / 3$ trial (i.e., NCT04368728) to further evaluate its safety and efficacy (21). BNT162b2 received EUA from the FDA on December 11, 2020, and from the European Commission on December 21, 2020, following the EMA recommendation of authorization. On December 31, 2020, the WHO granted its first emergency use listing for BNT162b2 (59).

CureVac's CVnCoV is also a lipid nanoparticleencapsulated mRNA vaccine encoding the full-length SARS-CoV-2 S glycoprotein (22). The preliminary results of a phase 1 clinical study (i.e., NCT04449276) showed the safety and tolerability of the $\mathrm{CVnCoV}$ vaccine in healthy volunteers 18-60 years of age (60).

\section{Plasmid DNA Vaccine}

Generally, DNA vaccines have good stability profiles compared to mRNA and protein subunit vaccines and no risk of infection compared to live-attenuated virus-based vaccines (13). Also, they are cost-effective, easily produced, and can induce durable immune responses (61). ZyCoV-D is a plasmid DNA vaccine candidate developed by Zydus Cadila (Ahmedabad, India) $(33,62)$. The results of phase $1 / 2$ clinical trial (i.e., CTRI/2020/07/026352) have not been published, and a phase 3 clinical trial (i.e., CTRI/2021/01/030416) evaluating the efficacy and safety of ZyCoV-D was initiated. $\mathrm{ZyCoV}-\mathrm{D}$ is given by intradermal injection using Pharmajet.
INO-4800 is another DNA vaccine developed by Inovio Pharmaceuticals. The vaccine is injected intradermally followed by electroporation using CELLECTRA ${ }^{\circledR}$. The electroporation generates a controlled electric field at the site of injection to ameliorate the cellular uptake and thus the expression of the DNA plasmid (35). Data from phase 1 clinical trial (i.e., NCT04336410) demonstrated the safety and tolerability of INO-4800, which also elicited humoral and/or cellular immune responses in all vaccinated subjects. (35).

\section{Recombinant Protein Subunit Vaccines}

Novavax's NVX-CoV2373 is adjuvanted with Matrix-M1. Matrix-M1 is a mixture of two different formulations of saponin in cholesterol and phospholipid-based nanoparticle (63). Matrix-M1 has not yet been approved for human use. The safety and immunogenicity of NVX-CoV2373 at a dose level of $5 \mu \mathrm{g}$ and $25 \mu \mathrm{g}$ with or without $50 \mu \mathrm{g}$ of Matrix-M1 adjuvant were evaluated in a randomized, placebo-controlled, phase 1/2 clinical trial (i.e., NCT04368988). Adjuvanted NVX-CoV237 was found to be safe and elicited immune responses that exceeded the responses in COVID-19 convalescent serum. Matrix-M1 adjuvant spared the antigen dose and helped induce $\mathrm{T}$ helper 1 response (64). Anhui Zhifei Longcom Biopharmaceutical and the Institute of Microbiology at the Chinese Academy of Sciences developed another protein subunit vaccine candidate which is currently in phase 3 clinical evaluation (i.e., ChiCTR2000040153).

\section{Virus-Like Particles}

As of January 28, 2021, the WHO official data showed only one SARS-CoV-2 virus-like particle (VLP) COVID-19 vaccine candidate (i.e., CoVLP) (12). CoVLP is adjuvanted with the adjuvant system AS03 that is composed of $\alpha$ tocopherol, squalene, and polysorbate 80 in an oil-in-water emulsion (36). None peer-reviewed data (i.e., preprint of a manuscript) of phase 1 clinical trial showed the tolerability and immunogenicity of CoVLP (i.e., eliciting strong humoral and cellular immune responses) (65).

\section{BCG Vaccine}

$\mathrm{BCG}$ vaccine is a vaccine that was originally developed to prevent tuberculosis (66). BCG can protect against multiple unrelated pathogens at least in part by the induction of innate immune memory (i.e., trained immunity). Thus, it has been hypothesized that BCG vaccination may protect against SARS-CoV-2 infection and/or reduce the severity of COVID-19 (67). The non-specific protective effect of BCG vaccination against SARS-CoV-2 infection in high-risk population is currently being evaluated in various phase 3 trials (e.g., healthcare workers [NCT04379336], elderly individuals [NCT04475302]).

\section{(PREDICTED) STORAGE TEMPERATURES FOR COVID-19 VACCINES IN PHASE 3 OR PHASE 2/3 CLINICAL TRIALS WITH OR WITHOUT EUA}

Generally, the costs of cold-chain storage and the logistics of vaccine distribution for subsequent administration 
are major challenges encountered by the global vaccination programs (68). Vaccines lose their potency slowly over time, but elevated temperatures accelerate this potency loss process (69). Thus, vaccines are generally stored at cold or ultracold temperatures to maintain their stability and immunogenicity, which are reduced even at moderate temperatures (68). As shown in Table II and Figure 1, vaccine heat sensitivity varies depending on the vaccine platform, and even vaccines based on the same platform have different stability profiles depending on the manufacturer.

Almost all licensed inactivated virus vaccines are required to be stored in cold temperatures (i.e., 2-8 ${ }^{\circ} \mathrm{C}$ ) (83). Almost all inactivated virus-based COVID-19 vaccine candidates currently in phase 3 or phase $2 / 3$ clinical trials contain an aluminum salt adjuvant (Table I). Therefore, they will most likely be stored at $2-8^{\circ} \mathrm{C}$. For example, SinoVac Biotechnology reported that its aluminum salt-adjuvanted, inactivated CoronaVac vaccine is stable for at least 5 months at $2-8^{\circ} \mathrm{C}, 42$ days at $25^{\circ} \mathrm{C}$ and 28 days at $37^{\circ} \mathrm{C}(80)$. Matthias et al. reported that $14-35 \%$ of refrigerators or shipments have exposed vaccines to freezing temperatures (84). Accidentally exposing aluminum-adjuvanted vaccines to freezing temperatures during transport or storage should be avoided, as the slow freezing (due to breach of cold chain) causes the aggregation of the aluminum salt particulates and the loss of the vaccine potency (85).

The Ad vector-based COVID-19 vaccines currently in phase 3 clinical trials most likely need to be stored at $2-8^{\circ} \mathrm{C}$ or in freezing temperatures. For example, Gamaleya's Ad5and Ad26-based liquid vaccine is recommended to be stored frozen in temperatures not higher than $-18^{\circ} \mathrm{C}$, although Gamaleya also has developed a freeze-dried form of the vaccine candidate, which is expected to be stable at $2-8^{\circ} \mathrm{C}$ (17).

Janssen's Ad26.CoV2.S vaccine is based on the same AdVac platform as its Zabdeno Ebola vaccine (i.e., Ad26.ZEBOV), which has been granted marketing authorization by the EMA. Formulation advances have allowed long-term storage of Ad26-based vaccines at $2-8^{\circ} \mathrm{C}(86)$. For instance, Zabdeno has a shelf-life of 4 years at -85 to $-55^{\circ} \mathrm{C}$. It should be transported frozen at -25 to $-15^{\circ} \mathrm{C}$ and can be stored by distributors or end users in a freezer at -25 to $-15^{\circ} \mathrm{C}$ for a period of up to 20 months. At $2-8^{\circ} \mathrm{C}$, it can be stored for up to 8 months (70). Therefore, it is expected that Ad26.CoV2.S

Table II. A Summary of the (Expected) Storage Temperatures and Shelf Lives of Selected COVID-19 Vaccine Candidates in Phase 3 or Phase 2/3 Clinical Trials

\begin{tabular}{|c|c|c|c|c|}
\hline Vaccine candidate & Dosage form & Dosing regimen $^{a}$ & $\begin{array}{l}\text { Expected storage } \\
\text { temperatures/shelf-life }^{\mathrm{b}}\end{array}$ & $\begin{array}{l}\text { Supporting } \\
\text { evidence }\end{array}$ \\
\hline $\begin{array}{l}\text { Sputnik V (rAd26-S } \\
\text { and rAd5-S) }\end{array}$ & $\begin{array}{l}\text { Frozen liquid } \\
\text { or freeze-dried } \\
\text { powder }\end{array}$ & $\begin{array}{l}\text { Two IM doses on days } 0 \\
\quad(\mathrm{rAd} 26-\mathrm{S}) \text { and } 21 \text { (rAd5-S) }\end{array}$ & $\begin{array}{l}\leq-18^{\circ} \mathrm{C} \text { (liquid form)/NA } \\
2-8^{\circ} \mathrm{C} \text { (lyophilized form)/NA }\end{array}$ & $(17)$ \\
\hline Ad26.CoV2.S & Liquid & $\begin{array}{l}\text { Single IM dose }\left(5 \times 10^{10}\right. \\
\text { virus particles })\end{array}$ & $\begin{array}{l}-85 \text { to }-55^{\circ} \mathrm{C} / 4 \text { years } \\
-25 \text { to }-15^{\circ} \mathrm{C} / 20 \text { months } \\
2-8^{\circ} \mathrm{C} / 6-8 \text { months }\end{array}$ & $(70-72)$ \\
\hline Ad5-based candidate & Liquid & Single IM dose & $2-8^{\circ} \mathrm{C} / 12$ months when lyophilized & $(73)$ \\
\hline AZD1222 (ChAdOx1-S) & Liquid & $\begin{array}{l}\text { Two IM doses }\left(5 \times 10^{10} \text { virus }\right. \\
\text { particles each) on days } 0 \text { and } 28\end{array}$ & $\begin{array}{l}2-8^{\circ} \mathrm{C} / 6 \text { months } \\
2-25^{\circ} \mathrm{C} / 6 \mathrm{~h}\end{array}$ & $(73,74)$ \\
\hline mRNA-1273 & Frozen liquid & $\begin{array}{l}\text { Two IM doses }(100 \mu \mathrm{g} \\
\text { mRNA each) on days } 0 \text { and } 28\end{array}$ & $\begin{array}{l}-20^{\circ} \mathrm{C} / 6 \text { months } \\
2-8^{\circ} \mathrm{C} / 30 \text { days } \\
25^{\circ} \mathrm{C} / 12 \mathrm{~h}\end{array}$ & $(75-78)$ \\
\hline Comirnaty® (BNT162b2) & Frozen liquid & Two IM doses on days 0 and 21 & $\begin{array}{l}-70^{\circ} \mathrm{C} / 6 \text { months } \\
2-8^{\circ} \mathrm{C} / 5 \text { days } \\
25^{\circ} \mathrm{C} / 2 \mathrm{~h}\end{array}$ & \\
\hline $\mathrm{CVnCoV}$ & Liquid & Two IM doses on days 0 and 28 & $\begin{array}{l}5^{\circ} \mathrm{C} / 3 \text { months } \\
25^{\circ} \mathrm{C} / 24 \mathrm{~h}\end{array}$ & $(79)$ \\
\hline NVX-CoV2373 & Liquid & Two IM doses on days 0 and 21 & $2-8^{\circ} \mathrm{C} / \mathrm{NA}$ & $(78)$ \\
\hline CoronaVac & Liquid & $\begin{array}{l}\text { Two IM doses of } \\
3 \mu \mathrm{g} / 0.5 \mathrm{~mL} \text { aluminum hydroxide } \\
\text { each on days } 0 \text { and } 14\end{array}$ & $\begin{array}{l}2-8^{\circ} \mathrm{C} / \text { at least } 5 \text { months } \\
25^{\circ} \mathrm{C} / 42 \text { days } \\
37^{\circ} \mathrm{C} / 28 \text { days }\end{array}$ & $(80)$ \\
\hline Inactivated vaccine & Liquid & Two IM doses on day 0 and on day 21 & $2-8^{\circ} \mathrm{C} / \mathrm{NA}$ & $(81)$ \\
\hline BBIBP-CorV & Liquid & Two IM doses on days 0 and 21 & $2-8^{\circ} \mathrm{C} / \mathrm{NA}$ & \\
\hline COVAXINTM (BBV152) & Liquid & Two IM doses $(6 \mu \mathrm{g} /$ dose $)$ on days 0 and 28 & $\begin{array}{l}37^{\circ} \mathrm{C} / 7 \text { days } \\
2-8^{\circ} \mathrm{C} / \mathrm{NA}\end{array}$ & $(31)$ \\
\hline ZyCoV-D & Liquid & Three ID doses on days 0,28 , and 56 & $\begin{array}{l}2-8^{\circ} \mathrm{C} / \mathrm{NA} \\
30^{\circ} \mathrm{C} / 3 \text { months }\end{array}$ & $(82)$ \\
\hline BCG & $\begin{array}{l}\text { Freeze-dried } \\
\text { powder }\end{array}$ & $\begin{array}{l}\text { Single ID dose }(75 \mu \mathrm{g} \text { live } \\
\text { attenuated bacteria) } \\
\text { Single ID dose }\left(2 \times 10^{5}-8 \times 10^{5} \mathrm{CFU}\right)\end{array}$ & $\begin{array}{l}2-8^{\circ} \mathrm{C} / 12-24 \text { months } \\
-25 \text { to }-15^{\circ} \mathrm{C} \text { is fine but } \\
\text { not necessary }\end{array}$ & $(37)$ \\
\hline
\end{tabular}

$C F U$ colony forming unit, $I D$ intradermal, $I M$ intramuscular, $N A$ no available data

${ }^{a}$ The dosing regimen is based on the ongoing Phase 3 or Phase $2 / 3$ clinical trials summarized in Table I

${ }^{b}$ The expected storage temperatures and the corresponding shelf-lives are based on information publicly stated by the developers/ manufactures or the stability profile of the corresponding platform used to develop these vaccine candidates 


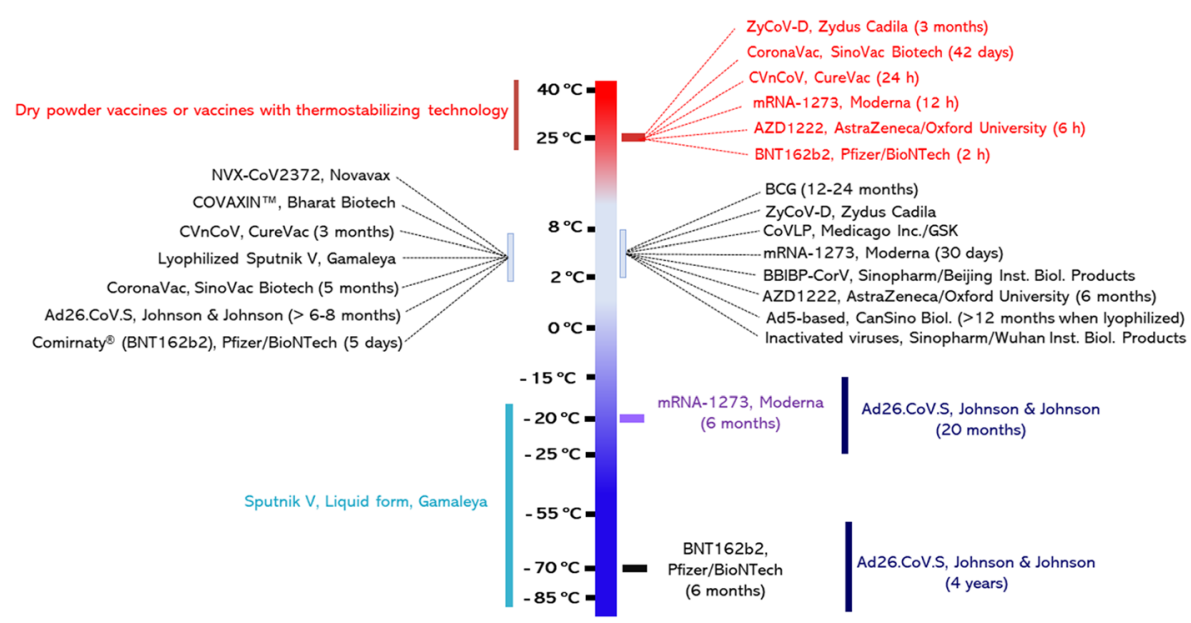

Fig. 1. Expected long-term storage temperatures and shelf-lives of various COVID-19 vaccine candidates in Phase 3 or Phase $2 / 3$ clinical trials. Thermostable vaccines can be developed via the inclusion of thermostabilizing technology or the transformation of liquid vaccines into dry powders

COVID-19 vaccine will likely have a similar thermostability profile, if a thermostabilizing technology will not be incorporated into the vaccine candidate (71).

CanSinoBio's Ad5-based COVID-19 vaccine uses the same platform as its Ad5-EBOV Ebola vaccine. The final formulation of the Ad5-EBOV is in a lyophilized form and has a shelf-life of 12 months at $2-8^{\circ} \mathrm{C}$ (73). Similarly, its Ad5based COVID-19 vaccine needs to be stored at $2-8^{\circ} \mathrm{C}(87)$.

AstraZeneca-Oxford's AZD1222 (i.e., ChAdOx1-S) vaccine candidate uses the same platform as its ChAdOx1-GnGc Rift Valley Fever vaccine. A sugar-membrane thermostabilized ChAdOx1-GnGc vaccine can be stored at $45^{\circ} \mathrm{C}$ for 6 months, and its immunogenicity was not different from that after the vaccine was stored at $-80^{\circ} \mathrm{C}$ for the same period of time (88). Sugarmembrane thermostabilizing technology relies on the formulation of thermosensitive vaccines in a solution of sucrose and trehalose which upon drying at room temperature forms thin coats of sugar glass (88). The embedded molecules can be stabilized via restricting their mobility (89). AZD1222 has a shelf-life of 6 months at $2-8^{\circ} \mathrm{C}$. Once the stopper of the vial has first been punctured, it was recommended that the vaccine should be stored between 2 and $25^{\circ} \mathrm{C}$ and used with $6 \mathrm{~h}$. Apparently, the aforementioned sugarmembrane thermostabilizing technology was not introduced in the ADZ1222 vaccine.

Messenger RNA vaccines are first in class globally. The two mRNA vaccines that have received EUA need to be stored frozen. Moderna's mRNA-1273 vaccine should be stored at $-20^{\circ} \mathrm{C}$, where it is potentially stable for 6 months. Recently, Moderna announced data for stability testing showing that its candidate vaccine remains stable at $2-8^{\circ} \mathrm{C}$ for 30 days and at $25^{\circ} \mathrm{C}$ for up to $12 \mathrm{~h}$ (75). Pfizer/BioNTech's $\mathrm{BNT} 162 \mathrm{~b} 2 \mathrm{mRNA}$ vaccine needs to be stored at $-70^{\circ} \mathrm{C}$, with a shelf-life of about 6 months. After the vaccine is thawed, it can be stored at $2-8^{\circ} \mathrm{C}$ for 5 days, and only $2 \mathrm{~h}$ at room temperature $(76,77)$. CureVac's $\mathrm{CVnCoV}$ mRNA vaccine is stable for 3 months at $5^{\circ} \mathrm{C}$ and $24 \mathrm{~h}$ at $25^{\circ} \mathrm{C}$. The different stability profiles of different mRNA vaccines are likely due to the differences in their mRNA lipid nanoparticle compositions and properties (90).

Novavax's NVX-CoV2373 adjuvanted with Matrix-M1 adjuvant is expected to be stored at $2-8^{\circ} \mathrm{C}(55)$. Matrix-M1 adjuvant can be frozen or lyophilized, but it is not clear whether Novavax will market a lyophilized powder form of its NVX-CoV2373 (91).

Finally, Zydus Cadila's plasmid DNA vaccine (i.e., $\mathrm{ZyCoV}-\mathrm{D})$ can be stored at $2-8^{\circ} \mathrm{C}$ or even at $30^{\circ} \mathrm{C}$ for 3 months (82). According to WHO recommendations, BCG vaccine should be stored and transported at $2-8^{\circ} \mathrm{C}$, although it can be stored at -25 to $-15^{\circ} \mathrm{C}$.

To summarize, for the inactivated virus-based COVID19 vaccines adjuvanted with an aluminum salt and the NVXCoV2373 adjuvanted with Matrix-M1 adjuvant, it is expected that cold temperatures of $2-8^{\circ} \mathrm{C}$ are sufficient for their storage and transport. The aluminum-adjuvanted inactivated virus-based vaccines in liquid suspension are expected to be sensitive to accidental freezing upon breach of cold chain (92). The NVX-CoV2373-Matrix-M1 vaccine may not be sensitive to freezing, because data from previous studies have shown that the Matrix-M1 (or ISCOMS) can be safely frozen (91). The Ad vector-based vaccine candidates are more likely to be stored at $2-8^{\circ} \mathrm{C}$. Storing them frozen at -25 to $-15^{\circ} \mathrm{C}$, although not required, would significantly increase their shelflives. For the two mRNA vaccines that have received EUA, they must be kept frozen in order to have a few months of shelf-life. For the BNT162b2 mRNA vaccine, $-70^{\circ} \mathrm{C}$ storage is required. CureVac's CVnCoV mRNA vaccine is stable for 3 months at $5^{\circ} \mathrm{C}$.

\section{COVID-19 VACCINES WITH FDA EUA AND THEIR DISTRIBUTION APPROACHES}

Pfizer/BioNTech's and Moderna's mRNA vaccines are first in class vaccines that were developed at an unprecedented speed, but both of them require freezing temperatures for storage and distribution. Their storage conditions and logistics for their distribution are described below.

\section{Pfizer/BioNTech's BNT162b2 mRNA Vaccine}

On November 18, 2020, Pfizer and BioNTech announced the results of the final efficacy analysis of their ongoing phase 3 clinical trial. Their mRNA-based BNT162b2 vaccine 
achieved an efficacy rate of $95 \%$ against COVID-19. In adults $>65$ years of age, it achieved an efficacy $>94 \%$ (93). Based on their current projections, Pfizer and BioNTech expect to manufacture up to 1.3 billion doses by the end of 2021 (53). On December 2, 2020, the UK MHRA awarded a temporary EUA for the Pfizer/BioNTech's BNT162b2 mRNA vaccine (94). The UK National Health Service (NHS) has launched the largest mass vaccination campaign in its history. The UK's vaccination program will initially include highly vulnerable elderly (95). The US FDA also granted Pfizer/BioNTech's BNT162b2 mRNA vaccine EUA on December 11, 2020.

Pfizer has developed logistical plans for effective vaccine transport, distribution and storage in the USA (77). Vaccine distribution is based on just-in-time system that will deliver the frozen vials directly to the point of use in a specially designed, temperature-controlled thermal shippers. The recommended storage temperature (i.e., $-70^{\circ} \mathrm{C} \pm 10^{\circ} \mathrm{C}$ ) is maintained for up to 10 days in the thermal shippers via utilization of dry ice. The location and storage temperature of vaccine shipments are tracked by global positioning system (GPS)-enabled thermal sensors (77). Pfizer has provided three options for the vaccine storage in the point of use: (i) storing the frozen vials in ultra-low temperature freezers for up to 6 months, (ii) storing the frozen vials temporarily in the thermal shippers for up to 30 days by refilling the dry ice every 5 days, or (iii) storing the vaccines in cold temperature (i.e., $2-8^{\circ} \mathrm{C}$ ) for 5 days. Thawed vials cannot be re-frozen (77). Although these plans are feasible for vaccine distribution in the USA, they require an efficient, ultra-cold network of grounds and air transport, which may not be available in many other countries that are also affected by COVID-19.

\section{Moderna's mRNA-1273 Vaccine}

On November 16, 2020, Moderna announced the results of the first interim analysis of its phase 3 clinical trial. Moderna's mRNA-1273 vaccine met its primary and secondary efficacy endpoints with an efficacy of $94.5 \%$ (96). Moderna expects the production of 500 million to 1 billion doses in 2021 globally (96).

Moderna's mRNA-1273 vaccine is shipped at standard freezer temperatures of $-20^{\circ} \mathrm{C} \pm 5^{\circ} \mathrm{C}$. After thawing at the point of use, it can be stored at $2-8^{\circ} \mathrm{C}$ for 30 days or at $25^{\circ} \mathrm{C}$ for $12 \mathrm{~h}$ (75). The enhanced stability profile of mRNA-1273 vaccine allows simpler and more flexible distribution compared to Pfizer/BioNTech's BNT162b2 mRNA vaccine, although storage and transport of multi-billion doses of vaccines in $-20^{\circ} \mathrm{C}$ is still prohibitory expensive in many countries.

\section{CHALLENGES OF DISTRIBUTING COVID-19 VAC- CINES IN COLD CHAIN}

The cold chain should be maintained from the time of vaccine manufacturing through the time of vaccine administration or just a few hours before the administration. Maintaining the cold chain is a shared responsibility of vaccine manufacturers, distributors, public health personnel, and health care providers. An efficient cold chain counts on three main elements, well-trained personnel, reliable storage and temperature monitoring equipment, and accurate vaccine inventory management (97).
Vaccine exposure to an inappropriate condition (e.g., accidental overheating or freezing due to the breach of the cold chain) may result in reduction of potency that could not be regained. For example, a single exposure of any refrigerated vaccine or diluent (e.g., diluents containing aluminum salts) to a freezing temperature (i.e., $\leq 0^{\circ} \mathrm{C}$ ) can destroy the vaccine (85). Populations who are unintentionally vaccinated with a vaccine exposed to inappropriate temperatures should be revaccinated, resulting in extra doses for the individual and extra costs for the provider, which is critical when rapid mass vaccination is required.

The requirement of the ultracold temperatures for the storage and transport of the most advanced COVID-19 mRNA vaccines, especially the $-70^{\circ} \mathrm{C}$ freezing condition required by the $\mathrm{BNT} 162 \mathrm{~b} 2$, is a major challenge towards vaccine distribution and thus rapid mass immunization, particularly in climatic zones IVa (i.e., $30^{\circ} \mathrm{C} / 65 \%$ relative humidity) and $\mathrm{IVb}$ (i.e., $30^{\circ} \mathrm{C} / 75 \%$ relative humidity) (98). These vaccines should be stored and transported in controlled environment to maintain their quality and potency. The storage and transport equipment (e.g., cold rooms, refrigerators, freezers, cold boxes, and the thermal shippers designed by Pfizer) are costly to acquire and should comply with the WHO standards. In countries and regions that have outdated technologies with poor temperature control, the vaccines can be potentially exposed to temperature fluctuations during storage and/or transport, resulting in vaccine wastage. Apart from the costs of maintaining the ultracold temperature added to the vaccination program, vaccine wastage slows the rate of vaccination during this pandemic. For the frozen mRNA vaccines, the time taken for the vaccines (i.e., stored at $-20^{\circ} \mathrm{C}$ or $-70^{\circ} \mathrm{C}$ ) to thaw (i.e., $\sim 2 \mathrm{~h}$ at $2-8^{\circ} \mathrm{C}, 30 \mathrm{~min}$ at room temperature (up to $25^{\circ} \mathrm{C}$ )) will add further challenge.

It is encouraging that some COVID-19 vaccines that have recently received EUA in various countries around the world do not need freezing temperatures for distribution and storage, and many other COVID-19 vaccines that are expected to receive EUA or final approval will likely also have sufficient shelf lives in $2-8^{\circ} \mathrm{C}$. In many communities around the world, the infrastructure for the $2-8^{\circ} \mathrm{C}$ is already in existence, and thus, many COVID-19 vaccine candidates with limited stability at ambient temperatures are expected to reach many end users. However, the existing cold chain will struggle to support both the standard national immunization programs and COVID-19 vaccines. Consequently, there is a critical need to integrate thermo-stabilizing technologies into future COVID-19 vaccines for the world to rapidly and cost-effectively vaccinate against COVID-19. Any significant delay in vaccinating a sufficient percent of the world populations to build herd immunity would give SARS-CoV-2 the chance to mutate to more infectious and/ or deadlier variants.

\section{EXISTING TECHNOLOGIES TO ELIMINATE REQUIREMENT OF COLD TEMPERATURE STORGE AND DISTRIBUTION OR AT LEAST AVOID THE NEED FOR AN ULTRACOLD TEMPERATURES}

There has been a strong and persistent interest in making vaccines stable at ambient temperatures, and various promising technologies have been developed. Optimizing the 
composition of vaccines by including certain polymers or sugars can make certain vaccines insensitive to freezing and/ or stable for months at room temperatures (99). Another very practical approach is to transform vaccines from liquid (or frozen liquid or frozen suspension) to dry powder for reconstitution at the point of administration. Several technologies have been tested to convert liquid vaccines into more stable dry powder form that can be stored in ambient temperatures for months, if not years. Thermal and mechanical stresses encountered during these drying processes can be overcome by using appropriate excipients and process parameters (100).

Conventional shelf freeze-drying is commonly utilized powder engineering technology to transform small molecule drugs as well as vaccines and other biologics into dry powders while maintaining stability and sterility (101). Excipients (e.g., sugars and amino acids) have been employed to preserve the activity of biologics during freeze-drying (102). Continuous freeze-drying has been proposed to enhance the uniformity of heat transfer and reduce the primary drying time (103). For instance, spin freeze-drying is a continuous freeze-drying technology in which the vial content is frozen by a cold gas as the vial is spun along its longitudinal axis. This innovative process provides numerous advantages over the conventional shelf freeze-drying including reduction of primary drying time, increasing the surface area for sublimation, and exposing all vials to the same process conditions (104).

Freeze-dried vaccine powders generally exhibit better stability as compared to their liquid counterparts. Most marketed freeze-dried vaccines are intended to be reconstituted before administration by injection (13). Freeze-drying has also been employed to transform vaccines into stable powders for needle-free noninvasive administration (e.g., modified vaccinia virus Ankara vaccine via the intranasal route) (105).

Limitations of traditional shelf freeze-drying technology include the phase separation as a result of the low cooling rate employed (i.e., 1-10 K/min) (106). Generally, slow cooling/freezing results in the formation of large ice crystals and solute concentrate in the non-ice-phase (i.e., 20-50-fold higher than the initial concentration) and thus phase separation between two or more excipients or between the protein and other excipients (106). Phase separation causes irreversible damage of proteins (e.g., denaturation, aggregation) $(107,108)$. Slow cooling of a protein solution generates powders with a large percent of particles of 4.8-120 microns (i.e., $95 \%$ ) with low specific surface area, which in turn limits their deliverability via some routes of administration (e.g., the pulmonary or intranasal) (109). Additionally, shelf freezedrying is challenged by the added costs of lyophilization (110).

Spray-drying is another technology for transforming vaccines into dry powders, usually in the presence of excipients (e.g., sugars, proteins, amino acids, polymers, surfactants, and plasticizers) $(111,112)$. It is cost-effective (i.e., consumes less energy compared to freeze-drying), can be scaled up in sterile environments, does not involve freezing or high vacuum, and can produce powder with suitable aerodynamic properties for potential pulmonary immunization. Spray-drying has been successfully employed to help maintain the viability of bacteria (e.g.,
Mycobacterium) and live-attenuated viruses (e.g., measles) in dry powder for up to four months at $25^{\circ} \mathrm{C}$ or $37^{\circ} \mathrm{C}$ $(100,113)$. This powder engineering technology has also been successfully utilized to transform an inactivated influenza vaccine into dry powder for intranasal vaccination (114).

Spray-drying is particularly important for preparing inhaled vaccine powders with enhanced long-term stability at room temperature (e.g., inhaled powder of influenza subunit vaccine) (112,115-117). It was also employed for the production of recombinant non-replicating human type-5 Ad and vesicular stomatitis virus (VSV)-coloaded coated powders for oral administration (68). Limitations of spray-drying include antigen exposure to high stresses during the atomization and drying steps and the possibility of antigen denaturation due to the formation of air-water interfaces during the atomization step and the heat stress applied to facilitate the evaporation of the solvent, into which the antigens and excipients are dissolved or dispersed (111).

Spray freeze-drying is a relatively recent drying technology that combines freeze-drying and spray-drying technologies. It includes three main steps: the atomization of bulk liquid into droplets, freezing of droplets in the presence of a cryogen (e.g., liquid nitrogen), and removal of ice via sublimation at very low pressure and temperature (118). It is advantageous in terms of providing high powder yield, fine control of particle characteristics, and reducing heat stress to biologics (119). An influenza subunit vaccine was formulated into a dry powder comprising trehalose, mannitol, and dextran by spray freeze-drying. The vaccine powder exhibited physical and biochemical stability for up to 1 year of storage at room temperature (119). Spray freeze-drying has also been utilized to formulate influenza vaccines as stable dry powders for intranasal or pulmonary vaccination to elicit both systemic and mucosal immune responses (112,120-122). It is also applicable for the transformation of vaccines containing aluminum salts into dry powder without showing signs of significant coagulation upon reconstitution (123). Recently, Qiu et al. developed mRNA-inhaled powder using spraydrying and spray freeze-dying technologies; however, the stability profile was not reported (124).

Limitations of spray freeze-drying include (i) high costs (i.e., 30-50-fold higher than spray-drying), (ii) the majority of developed spray freeze-drying units are not suitable for full commercialization, (iii) unwanted fine powder elutriation, and (iv) high interfacial tension of the atomized droplets (118). The adsorption of proteins at the air-liquid interface during atomization is a major source of protein aggregation and loss of biological activity (125). The freezing step could also result in ice crystallization and phase separation (126). Other technologies include foam-drying that has been employed to convert a live attenuated H1N1 influenza vaccine to a dry powder that was stable for $>1.5$ years at room temperature (127).

Thin-film freeze-drying (TFFD) is a relatively new powder engineering technology that has showed promise in the formulation of thermostable vaccine dry powders. Thinfilm freezing (TFF) is an ultra-rapid freezing process in which a liquid formulation (i.e., aqueous phase or organic phase solution/suspension with/without excipients) of the active pharmaceutical ingredient (e.g., small molecules, macromolecules, or viruses) is dropped (e.g., droplet diameter around 2- 
$4 \mathrm{~mm}$ ) onto a cryogenically cooled surface, forming thin films upon impact, which then rapidly freeze, and the frozen films are subsequently placed in a lyophilizer to allow the sublimation of the solvent (128-130). TFFD can produce highly porous, low-density brittle matrix powders with good aerosol properties for lung deposition by inhalation (131136). Importantly, the stability and activity of the biologics are maintained after subject to TFFD (129). The freezing rate during TFF is significantly higher than during conventional shelf freeze-drying, but lower than during spray freeze-drying; however, TFF reduces the gas-liquid interface by up to two orders of magnitude as compared to spray freeze-drying (109). During TFF, there is an added liquid-solid interface between the thinfilms before they are frozen and a cryogenically cooled solid surface.

Previously, the TFFD technology has been utilized to successfully convert some commercially available insoluble aluminum salt-adjuvanted liquid vaccines (i.e., veterinary tetanus toxoid vaccine, human hepatitis B vaccine, and human papilloma virus vaccine) into dry powders while maintaining their immunogenicity and particle size distribution after reconstitution (92). The preserved particle size distribution and immunogenicity of aluminum salt-adjuvanted vaccines after TFFD may be attributed to the rapid cooling rate (i.e., $100-1000 \mathrm{~K} / \mathrm{s}$ ) that prevents particle aggregation via accelerating the nucleation rate and the formation of small ice crystals $(109,119,137)$. The immunogenicity of thinfilm freeze-dried, Alhydrogel ${ }^{\circledR}$ (i.e., aluminum hydroxide)adjuvanted ovalbumin model vaccine did not significantly change after the model vaccine in dry powder was exposed to repeated freeze-thawing or to temperatures as high as $40^{\circ} \mathrm{C}$ for 3 months (138). The potential of using the thin-film freeze-dried vaccine powder for mucosal vaccination has also been explored. Intranasal vaccination using Alhydrogel ${ }^{\circledR}$-adjuvanted ovalbumin dry powder (as a model vaccine) elicited specific antibodies in rat serum samples and mucosal secretions (i.e., $\operatorname{IgA}$ in the nasal and lung mucosal secretions) (139). Finally, data from our recent studies showed that mRNA-encapsulated lipid nanoparticles can also be successfully converted to dry powders with good aerosol properties, while preserving the particle size using TFFD (unpublished data). These promising preclinical data together with the ease of using TFFD to produce powders in their final packaging containers suggest TFFD as a promising technology for the production of thermostable vaccine powders that do not need to be stored in a cold temperature. TFFD is currently used to cGMP manufacture materials for phase $1 / 2$ clinical trials (unpublished data); however, the requirement of large quantities of cryogens to produce and maintain a cryogenically cooled surface as well as the added costs of lyophilization are limitations (129).

Finally, due to the ideal aerosol performance properties of the powders prepared by TFFD, the resultant dry powder vaccines are expected to be deliverable through a non-invasive route such as intranasal or pulmonary administration $(129,140)$. In fact, intranasal DelNS1-2019-nCoV-RBD-OPT1, a COVID-19 vaccine candidate based on influenza virus carrying SARS-CoV-2 RBD, has entered phase 1 clinical trial recently (i.e., ChiCTR2000037782) (141). Altimmune's Ad vector-based AdCOVID vaccine candidate intended for intranasal vaccination is expected to enter phase 1 clinical trial soon (142). Finally, Codagenix and the Serum Institute of India have begun a first-inhuman clinical trial of their single-dose intranasal COVI-VAC COVID-19 vaccine (143). Therefore, it is not unreasonable to expect a future approved of intranasal COVID-19 vaccine. Technologies such as TFFD and spray drying can be used to convert the vaccines into stable inhaled dry powders for more efficient distribution and vaccination.

\section{CONCLUSIONS AND PERSPECTIVES}

The most advanced COVID-19 vaccine candidates that are currently in phase 3 or phase $2 / 3$ clinical trials or have been granted EUA are all expected to be stored and transported at cold or ultracold temperatures (i.e., $2-8^{\circ} \mathrm{C}$, or $-20^{\circ} \mathrm{C}$ or $-70^{\circ} \mathrm{C}$ ). Thus, even if all of them are successfully commercialized, rapid mass immunization of the world population is expected to be challenged by the costs and logistics needed to maintain the vaccines in the (ultra)cold temperatures during transport, storage, and distribution, particularly in less developed communities. Moreover, existing cold chain will struggle to support both the standard national immunization programs and COVID-19 vaccines (98). For some of the vaccines, accidental breach of the cold chain may result in immunization failure or vaccine wastage.

Mathematical simulation of vaccination revealed that factors associated with execution are more important in the effectiveness of global vaccination programs than the vaccines' immunogenicity established in the clinical studies (144). Thus, the efficiency of vaccine manufacturing and distribution along with other factors such as pandemic severity and public preparation should be considered during the development of effective vaccine candidates. "Even a vaccine that is only $50 \%$ effective in preventing disease could quell the pandemic if it were distributed quickly enough," said Jason L. Schwartz of Yale School of Public Health (145). According to the FDA guidance document for industry, a minimum primary efficacy threshold of $50 \%$ will ensure the effectiveness of COVID-19 vaccine candidate (146). Thus, the efficiency of vaccine distribution must be considered while developing next generation COVID-19 vaccines. Importantly, there are existing technologies that can be applied to transform most, if not all, the vaccines into dry powders to overcome the strict cold or ultracold temperature requirement to ultimately improve the efficiency of vaccine distribution. Vaccine developers must be incentivized to prioritize vaccine stability outside the cold chain. It is understandable that during the early phase of the race for safe and effective SARS-CoV-2 vaccines, logistics for distribution and storage stability were not be a priority to vaccine developers. In the next phase of vaccine development, more thermostable second-generation vaccines must be developed.

\section{ACKNOWLEDGEMENTS}

K.A. would like to express his appreciation for the financial support provided by the Egyptian Ministry of Higher Education and Scientific Research.

\section{DECLARATIONS}

Conflict of Interest ZC and ROW declare conflict of interest with TFF Pharmaceuticals, Inc, which has been reviewed and approved by UT Austin in accordance with its policy on objectivity in research. 


\section{REFERENCES}

1. Machhi J, Herskovitz J, Senan AM, Dutta D, Nath B, Oleynikov $\mathrm{MD}$, et al. The natural history, pathobiology, and clinical manifestations of SARS-CoV-2 infections. J NeuroImmune Pharmacol. 2020;15(3):359-86. https://doi.org/10.1007/s11481-020-09944-5.

2. Sultan S, Lim JK, Altayar O, Davitkov P, Feuerstein JD, Siddique SM, et al. AGA rapid recommendations for gastrointestinal procedures during the COVID-19 pandemic. Gastroenterology. 2020;159(2):739-58.e4. https://doi.org/10.1053/ j.gastro.2020.03.072.

3. Al-Qahtani AA. Severe acute respiratory syndrome coronavirus 2 (SARS-CoV-2): emergence, history, basic and clinical aspects. Saudi J Biol Sci. 2020;27:2531-8. https://doi.org/ 10.1016/j.sjbs.2020.04.033.

4. Abbott TR, Dhamdhere G, Liu Y, Lin X, Goudy L, Zeng L, et al. Development of CRISPR as an antiviral strategy to combat SARS-CoV-2 and influenza. Cell. 2020;181(4):86576.e12. https://doi.org/10.1016/j.cell.2020.04.020.

5. Wang C, Li W, Drabek D, Okba NMA, van Haperen R, Osterhaus A, et al. A human monoclonal antibody blocking SARS-CoV-2 infection. Nat Commun. 2020;11(1):2251. https:// doi.org/10.1038/s41467-020-16256-y.

6. Martines RB, Ritter JM, Matkovic E, Gary J, Bollweg BC, Bullock $\mathrm{H}$, et al. Pathology and pathogenesis of SARS-CoV-2 associated with fatal coronavirus disease. United States Emerg Infect Dis. 2020;26(9):2005-15. https://doi.org/10.3201/ eid2609.202095.

7. Hogan CA, Stevens B, Sahoo MK, Huang C, Garamani N, Gombar S, et al. High frequency of SARS-CoV-2 RNAemia and association with severe disease. medRxiv. 2020:2020.04.26.20080101. https://doi.org/10.1101/ 2020.04.26.20080101.

8. "Coronavirus disease (COVID-19) pandemic 2020". The World Health Organization 2020. https://www.who.int/emergencies/diseases/novel-coronavirus-2019? gclid $=\mathrm{Cj} 0 \mathrm{KCQj}$ wuL_8BRCXARIsAGiC51BtocY4nbwWsuHYrTpQ6qDtViakjUEglLqXqIRzGKC7cg_twv-muwMaAi2eEALw_wcB. Accessed 31 January 2021.

9. Chen X, Fernando GJ, Crichton ML, Flaim C, Yukiko SR, Fairmaid EJ, et al. Improving the reach of vaccines to lowresource regions, with a needle-free vaccine delivery device and long-term thermostabilization. J Control Release. 2011;152(3):349-55. https://doi.org/10.1016/ j.jconrel.2011.02.026.

10. "1,900 COVID vaccine doses ruined at Boston VA hospital after freezer accidentally unplugged". CBC News, January 22, 2021, Accessed January 26, 2021. https://www.cbsnews.com/ news/1900-covid-vaccine-doses-spoiled-boston-va-hospital/.

11. Jeyanathan M, Afkhami S, Smaill F, Miller MS, Lichty BD, Xing Z. Immunological considerations for COVID-19 vaccine strategies. Nat Rev Immunol. 2020;20(10):615-32. https:// doi.org/10.1038/s41577-020-00434-6.

12. "DRAFT landscape of COVID-19 candidate vaccines". The World Health Organization. https:/www.who.int/publications/m/item/draftlandscape-of-covid-19-candidate-vaccines. Accessed 8 Oct 2020.

13. Wang J, Peng Y, Xu H, Cui Z, Williams RO 3rd. The COVID19 vaccine race: challenges and opportunities in vaccine formulation. AAPS PharmSciTech. 2020;21(6):225. https:// doi.org/10.1208/s12249-020-01744-7.

14. Thanh Le T, Andreadakis Z, Kumar A, Gómez Román R, Tollefsen S, Saville M, et al. The COVID-19 vaccine development landscape. Nat Rev Drug Discov. 2020;19(5):305-6. https://doi.org/10.1038/d41573-020-00073-5.

15. Hotez PJ, Corry DB, Bottazzi ME. COVID-19 vaccine design: the Janus face of immune enhancement. Nat Rev Immunol. 2020;20(6):347-8. https://doi.org/10.1038/s41577-020-0323-4.

16. Mullard A. COVID-19 vaccine development pipeline gears up. Lancet. 2020;395(10239):1751-2. https://doi.org/10.1016/s01406736(20)31252-6.

17. Logunov DY, Dolzhikova IV, Zubkova OV, Tukhvatullin AI, Shcheblyakov DV, Dzharullaeva AS, et al. Safety and immunogenicity of an rAd26 and rAd5 vector-based heterologous prime-boost COVID-19 vaccine in two formulations: two open, non-randomised phase $1 / 2$ studies from Russia. Lancet. 2020;396(10255):887-97. https://doi.org/10.1016/s01406736(20)31866-3.

18. Zhu FC, Li YH, Guan XH, Hou LH, Wang WJ, Li JX, et al. Safety, tolerability, and immunogenicity of a recombinant adenovirus type-5 vectored COVID-19 vaccine: a dose-escalation, open-label, non-randomised, first-in-human trial. Lancet. 2020;395(10240):1845-54. https://doi.org/10.1016/s01406736(20)31208-3.

19. Sadoff J, Le Gars M, Shukarev G, Heerwegh D, Truyers C, de Groot AM, et al. Interim results of a phase 1-2a trial of Ad26.COV2.S Covid-19 Vaccine. N Engl J Med. 2021. https:// doi.org/10.1056/NEJMoa2034201.

20. Jackson LA, Anderson EJ, Rouphael NG, Roberts PC, Makhene M, Coler RN, et al. An mRNA vaccine against SARS-CoV-2 - preliminary report. N Engl J Med. 2020;383:1920-31. https://doi.org/10.1056/NEJMoa2022483.

21. Walsh EE, Frenck R, Falsey AR, Kitchin N, Absalon J, Gurtman A, et al. RNA-based COVID-19 vaccine BNT162b2 selected for a pivotal efficacy study. medRxiv. 2020. https:// doi.org/10.1101/2020.08.17.20176651.

22. Rauch S, Roth N, Schwendt K, Fotin-Mleczek M, Mueller SO, Petsch B. mRNA based SARS-CoV-2 vaccine candidate $\mathrm{CVnCoV}$ induces high levels of virus neutralizing antibodies and mediates protection in rodents. bioRxiv. 2020:2020.10.23.351775. doi: 10.1101/2020.10.23.351775.

23. Guebre-Xabier M, Patel N, Tian JH, Zhou B, Maciejewski S, Lam K, et al. NVX-CoV2373 vaccine protects cynomolgus macaque upper and lower airways against SARS-CoV-2 challenge. Vaccine. 2020;38(50):7892-6. https://doi.org/ 10.1016/j.vaccine.2020.10.064.

24. Yang S, Li Y, Dai L, Wang J, He P, Li C, et al. Safety and immunogenicity of a recombinant tandem-repeat dimeric RBD protein vaccine against COVID-19 in adults: pooled analysis of two randomized, double-blind, placebo-controlled, phase 1 and 2 trials. medRxiv. 2020:2020.12.20.20248602. https://doi.org/ $10.1101 / 2020.12 .20 .20248602$.

25. "Clover and GSK announce research collaboration to evaluate coronavirus (COVID-19) vaccine candidate with pandemic adjuvant system". Clover Biopharmaceuticals, February 24, 2020, accessed January 28, 2021. https://www.cloverbiopharma.com/2020/02/24/clover-and-gsk-announce-research-collaboration-to-evaluate-coronavirus-covid-19-vaccine-candidatewith-pandemic-adjuvant-system/.

26. "Covaxx announces $\$ 2.8$ billion in advance purchase commitments to deliver more than 140 million vaccine doses to emerging countries". Covaxx, November 25, 2020. accessed January 28, 2021. https://covaxx.reportablenews.com/pr/ covaxx-to-deliver-2-8-billion-in-vaccine-advance-purchasecommitments-110-million-doses-to-emerging-countries.

27. Cohen J. Vaccine designers take first shots at COVID-19. Science. 2020;368(6486):14-6. https://doi.org/10.1126/ science.368.6486.14.

28. "Clinical trial to evaluate the efficacy, immunogenicity and safety of the inactivated SARS-CoV-2 vaccine (COVID-19)". Clinical Trials.gov. https://clinicaltrials.gov/ct2/show/ NCT04560881? term $=$ vaccine $\&$ cond $=$ covid $-19 \&$ draw $=2$. Accessed 12 Oct 2020.

29. Isakova-Sivak I, Rudenko L. A promising inactivated wholevirion SARS-CoV-2 vaccine. Lancet Infect Dis. 2021;21(1):2-3. https://doi.org/10.1016/S1473-3099(20)30832-X.

30. "The efficacy, safety and immunogenicity study of inactivated SARS-CoV-2 vaccine for preventing against COVID-19". ClinicalTrials.gov, December 9, 2020, accessed January 28, 2021. https://clinicaltrials.gov/ct2/show/NCT04659239.

31. Ganneru B, Jogdand H, Dharam VK, Molugu NR, Prasad SD, Vellimudu S, et al. Evaluation of safety and immunogenicity of an adjuvanted, TH-1 skewed, whole virion inactivated SARSCoV-2 vaccine - BBV152. bioRxiv. 2020:2020.09.09.285445. https://doi.org/10.1101/2020.09.09.285445.

32. Huang Q, Yan J. SARS-CoV-2 virus: vaccines in development. Fundamental Res. 2021. https://doi.org/10.1016/ j.fmre.2021.01.009.

33. Sachdeva S, Gupta U, Prakash A, Margekar S, Sud R. The race to find COVID-19 vaccine: so near, yet so far! Indian J 
Medical Spec. 2020;11:175. https://doi.org/10.1101/ 2021.01.26.428240.

34. "Information on COVID-19". AnGes, accessed January 28, 2021. https://www.anges.co.jp/en/progress/.

35. Tebas P, Yang S, Boyer JD, Reuschel EL, Patel A, ChristensenQuick A, et al. Safety and immunogenicity of INO-4800 DNA vaccine against SARS-CoV-2: a preliminary report of an openlabel, Phase 1 clinical trial. EClinicalMedicine. 2020;100689:100689. https://doi.org/10.1016/j.eclinm.2020.100689.

36. "Medicago and GSK announce start of phase $2 / 3$ clinical trials of adjuvanted COVID-19 vaccine candidate". Medicago Inc., November 12, 2020, accessed January 28, 2021. https:// www.medicago.com/en/media-room/medicago-and-gsk-announce-start-of-phase-2-3-clinical-trials-of-adjuvanted-covid19-vaccine-candidate/.

37. "BCG vaccine handling". The World Health Organization. http://extranet.who.int/ivb_policies/reports/vaccine_handling.pdf. Accessed 11 Oct 2020.

38. The L. Global governance for COVID-19 vaccines. Lancet. 2020;395(10241):1883. https://doi.org/10.1016/s01406736(20)31405-7.

39. Folegatti PM, Ewer KJ, Aley PK, Angus B, Becker S, BelijRammerstorfer S, et al. Safety and immunogenicity of the ChAdOx1 nCoV-19 vaccine against SARS-CoV-2: a preliminary report of a phase $1 / 2$, single-blind, randomised controlled trial. Lancet. 2020;396(10249):467-78. https://doi.org/10.1016/ s0140-6736(20)31604-4.

40. Voysey M, Clemens SAC, Madhi SA, Weckx LY, Folegatti PM, Aley PK, et al. Safety and efficacy of the ChAdOx1 nCoV-19 vaccine (AZD1222) against SARS-CoV-2: an interim analysis of four randomised controlled trials in Brazil, South Africa, and the UK. Lancet. 2021. https://doi.org/10.1016/S01406736(20)32661-1.

41. “AstraZeneca's COVID-19 vaccine authorised for emergency supply in the UK". AstraZeneca, December 30, 2020, accessedd January 26, 2021. https://www.astrazeneca.com/content/ astraz/media-centre/press-releases/2020/astrazenecas-covid-19vaccine-authorised-in-uk.html.

42. Sadoff J, Le Gars M, Shukarev G, Heerwegh D, Truyers C, de Groot AM, et al. Safety and immunogenicity of the Ad26.COV2.S COVID-19 vaccine candidate: interim results of a phase $1 / 2 \mathrm{a}$, double-blind, randomized, placebo-controlled trial. medRxiv. 2020:2020.09.23.20199604. https://doi.org/ 10.1101/2020.09.23.20199604.

43. Ye T, Zhong Z, García-Sastre A, Schotsaert M, De Geest BG. Current status of COVID-19 (pre)clinical vaccine development. Angew Chem Int Ed Eng. 2020;59:18885-97. https:// doi.org/10.1002/anie.202008319.

44. Gao Q, Bao L, Mao H, Wang L, Xu K, Yang M, et al. Development of an inactivated vaccine candidate for SARSCoV-2. Science. 2020;369(6499):77-81. https://doi.org/10.1126/ science.abc1932.

45. Tseng CT, Sbrana E, Iwata-Yoshikawa N, Newman PC, Garron T, Atmar RL, et al. Immunization with SARS coronavirus vaccines leads to pulmonary immunopathology on challenge with the SARS virus. PLoS One. 2012;7(4):e35421. https://doi.org/10.1371/journal.pone.0035421.

46. Yong CY, Ong HK, Yeap SK, Ho KL, Tan WS. Recent advances in the vaccine development against Middle East respiratory syndrome-coronavirus. Front Microbiol. 2019;10:1781. https://doi.org/10.3389/fmicb.2019.01781.

47. Xia S, Duan K, Zhang Y, Zhao D, Zhang H, Xie Z, et al. Effect of an inactivated vaccine against SARS-CoV-2 on safety and immunogenicity outcomes: interim analysis of 2 randomized clinical trials. Jama. 2020;324(10):951-60. https://doi.org/ 10.1001/jama.2020.15543.

48. Xia S, Zhang Y, Wang Y, Wang H, Yang Y, Gao GF, et al. Safety and immunogenicity of an inactivated SARS-CoV-2 vaccine, BBIBP-CorV: a randomised, double-blind, placebocontrolled, phase 1/2 trial. Lancet Infect Dis. 2020;21:39-51. https://doi.org/10.1016/s1473-3099(20)30831-8.

49. Craven J. "COVID-19 vaccine tracker". Regulatory Affairs Professionals Society (RAPS), January 21, 2021, accessed January 26, 2021. https://www.raps.org/news-and-articles/newsarticles/2020/3/covid-19-vaccine-tracker.
50. Mohapatra PR, Mishra B. Regulatory approval of COVID-19 vaccine for restricted use in clinical trial mode. Lancet Infect Dis. 2021. https://doi.org/10.1016/S1473-3099(21)00045-1.

51. Corbett KS, Flynn B, Foulds KE, Francica JR, BoyogluBarnum S, Werner AP, et al. Evaluation of the mRNA-1273 vaccine against SARS-CoV-2 in nonhuman primates. N Engl J Med. 2020;383:1544-55. https://doi.org/10.1056/ NEJMoa2024671.

52. Wang F, Kream RM, Stefano GB. An evidence based perspective on mRNA-SARS-CoV-2 vaccine development. Med Sci Monit. 2020;26:e924700. doi: 10.12659/msm.924700.

53. "Our covid-19 vaccine study - what's next?". Pfizer Inc., November 20, 2020, accessed December 8, 2020. https://www.pfizer.com/ news/hot-topics/our_covid_19_vaccine_study_what_s_next.

54. Baric RS. Emergence of a highly fit SARS-CoV-2 variant. N Engl J Med. 2020;383:2684-6. https://doi.org/10.1056/ NEJMcibr2032888.

55. Alturki SO, Alturki SO, Connors J, Cusimano G, Kutzler MA, Izmirly AM, et al. The 2020 pandemic: current SARS-CoV-2 vaccine development. Front Immunol. 2020;11:1880. https:// doi.org/10.3389/fimmu.2020.01880.

56. Anderson EJ, Rouphael NG, Widge AT, Jackson LA, Roberts PC, Makhene M, et al. Safety and immunogenicity of SARSCoV-2 mRNA-1273 vaccine in older adults. N Engl $\mathrm{J}$ Med. 2020;383:2427-38. https://doi.org/10.1056/NEJMoa2028436.

57. Widge AT, Rouphael NG, Jackson LA, Anderson EJ, Roberts PC, Makhene M, et al. Durability of responses after SARSCoV-2 mRNA-1273 vaccination. N Engl J Med. 2020;384:80-2. https://doi.org/10.1056/NEJMc2032195.

58. Mulligan MJ, Lyke KE, Kitchin N, Absalon J, Gurtman A, Lockhart S, et al. Phase 1/2 study of COVID-19 RNA vaccine BNT162b1 in adults. Nature. 2020;586:589-93. https://doi.org/ 10.1038/s41586-020-2639-4.

59. "WHO issues its first emergency use validation for a COVID19 vaccine and emphasizes need for equitable global access". The World Health Organization, December 31, 2020, accessed January 26, 2021. https://www.who.int/news/item/31-12-2020who-issues-its-first-emergency-use-validation-for-a-covid-19vaccine-and-emphasizes-need-for-equitable-global-access.

60. Kremsner P, Mann P, Bosch J, Fendel R, Gabor JJ, Kreidenweiss A, et al. Phase 1 assessment of the safety and immunogenicity of an mRNA- lipid nanoparticle vaccine candidate against SARS-CoV-2 in human volunteers. medRxiv. 2020:2020.11.09.20228551. https://doi.org/10.1101/ 2020.11.09.20228551.

61. Baviskar T, Raut D, Bhatt LK. Deciphering Vaccines for COVID-19: where do we stand today? Immunopharmacol Immunotoxicol. 2021;43(1):8-21. https://doi.org/10.1080/ 08923973.2020 .1837867

62. Yadav S, Rawal G. The coronavirus disease 2019 vaccine-a step to halt the devastation by the pandemic of SARS-CoV-2.

63. Coleman CM, Liu YV, Mu H, Taylor JK, Massare M, Flyer DC, et al. Purified coronavirus spike protein nanoparticles induce coronavirus neutralizing antibodies in mice. Vaccine. 2014;32(26):3169-74. https://doi.org/10.1016/ j.vaccine.2014.04.016.

64. Keech C, Albert G, Cho I, Robertson A, Reed P, Neal S, et al. Phase 1-2 trial of a SARS-CoV-2 recombinant spike protein nanoparticle vaccine. N Engl J Med. 2020;383:2320-32. https:// doi.org/10.1056/NEJMoa2026920.

65. Ward BJ, Gobeil P, Séguin A, Atkins J, Boulay I, Charbonneau P-Y, et al. Phase 1 trial of a candidate recombinant viruslike particle vaccine for Covid-19 disease produced in plants. medRxiv. 2020:2020.11.04.20226282. doi: 10.1101/ 2020.11.04.20226282.

66. Redelman-Sidi G. Could BCG be used to protect against COVID-19? Nat Rev Urol. 2020;17(6):316-7. https://doi.org/ 10.1038/s41585-020-0325-9.

67. O'Neill LAJ, Netea MG. BCG-induced trained immunity: can it offer protection against COVID-19? Nat Rev Immunol. 2020;20(6):335-7. https://doi.org/10.1038/s41577-020-0337-y.

68. LeClair DA, Cranston ED, Lichty BD, Xing Z, Thompson MR. Consecutive spray drying to produce coated dry powder vaccines suitable for oral administration. ACS Biomater Sci 
Eng. 2018;4(5):1669-78. https://doi.org/10.1021/ acsbiomaterials. 8 b00117.

69. Hanson CM, George AM, Sawadogo A, Schreiber B. Is freezing in the vaccine cold chain an ongoing issue? A literature review. Vaccine. 2017;35(17):2127-33. https:// doi.org/10.1016/j.vaccine.2016.09.070.

70. "Summary of Zabdeno Ebola vaccine characteristics". European Medicines Agency. https://www.ema.europa.eu/en/documents/product-information/zabdeno-epar-product-information_en.pdf. Accessed 11 Oct 2020,

71. Funk $C D$, Laferrière $C$, Ardakani $A$. A snapshot of the global race for vaccines targeting SARS-CoV-2 and the COVID-19 pandemic. Front Pharmacol. 2020;11:937. https://doi.org/ 10.3389/fphar.2020.00937.

72. Sagonowsky EL, Angus; Blankenship, Kyle ; Hale, Conor; Kansteiner, Fraiser "COVID-19 tracker: Lilly's antibody plant tagged again by FDA; Pfizer preps massive vaccine distribution effort". Fierce Pharma, October 21, 2020, accessed October 21, 2020, https://www.fiercepharma.com/pharma/coronavirustracker-novavax-boasts-billion-plus-shot-capacity-by-2021-russia-s-world-first.

73. "Overview of candidate Ebola vaccines as of August 19, 2019". The World Health Organization, August 19, 201. https:// www.who.int/immunization/sage/meetings/2019/october/ 6_Ebola_Candidate_Vaccines_19-09-19.pdf. , Accessed 11 Oct 2020

74. HERPER MG, DAMIAN; BRANSWELL, HELEN "Studies provide glimpse at efficacy of Covid-19 vaccines from OxfordAstraZeneca and CanSino". Stat News, July 20, 2020, accessed October 21, 2020, https://www.statnews.com/2020/07/20/studyprovides-first-glimpse-of-efficacy-of-oxford-astrazeneca-covid19-vaccine/.

75. "Moderna announces longer shelf life for its COVID-19 vaccine candidate at refrigerated temperatures". Moderna Inc., November 16, 2020, accessed December 9, 2020. https:// investors.modernatx.com/news-releases/news-release-details/ moderna-announces-longer-shelf-life-its-covid-19-vaccine.

76. Lee J. "Moderna and Pfizer's COVID-19 vaccine candidates require ultra-low temperatures, raising questions about storage, distribution." Marketwatch, August 31, 2020,https:// www.marketwatch.com/story/moderna-and-pfizers-covid-19vaccine-candidates-require-ultra-low-temperatures-raisingquestions-about-storage-distribution-2020-08-27

77. "COVID-19 vaccine US distribution fact sheet". Pfizer Inc., November 20, 2020, accessed December 9, 2020. https://www.pfizer.com/news/hot-topics/covid_19_vaccine_u_s_distribution_fact_sheet

78. Armstrong M. "Moderna's Covid-19 vaccine looks golden in oldies". Evaluate, August 27, 2020, accessed October 13, 2020, https://www.evaluate.com/vantage/articles/news/trial-results/ modernas-covid-19-vaccine-looks-golden-oldies.

79. "Activities regarding $\mathrm{CVnCoV}$, CureVac's mRNA-based vaccine candidate against COVID-19". CureVac, January 19, 2021, accessed January 26, 2021. https://www.curevac.com/en/covid$19 /$

80. "China's Sinovac coronavirus vaccine candidate appears safe, slightly weaker in elderly". Reuters, 2020. https://www.reuters.com/article/us-health-coronavirus-vaccine-sinovac/chinassinovac-coronavirus-vaccine-candidate-appears-safe-slightlyweaker-in-elderly-idUSKBN25Y1QM. Accessed 12 Oct 2020. .

81. DeFrancesco L. Whither COVID-19 vaccines? Nat Biotechnol. 2020;38(10):1132-45. https://doi.org/10.1038/s41587-020-0697-7.

82. Das S. "ZyCoV-D shot can remain stable at room temperature: Zydus Cadila chairman". Business Standard, December 12, 2020, accessed January 26, 2021. https://www.business-standard.com/article/current-affairs/zycov-d-shot-can-remain-stableat - room-temperature-zydus-cadila-chairman120121200544_1.html.

83. World Health O. Temperature sensitivity of vaccines. Geneva: World Health Organization; 2006.

84. Matthias DM, Robertson J, Garrison MM, Newland S, Nelson C. Freezing temperatures in the vaccine cold chain: a systematic literature review. Vaccine. 2007;25(20):3980-6. https://doi.org/10.1016/j.vaccine.2007.02.052.

85. "Summary of stability data for licensed vaccines 2012", PATH Vaccine and Pharmaceutical Technologies Group, November
29, 2012. https://path.azureedge.net/media/documents/TS_vaccine_stability_table.pdf. Accessed 11 Oct 2020.

86. Custers J, Kim D, Leyssen M, Gurwith M, Tomaka F, Robertson J, et al. Vaccines based on replication incompetent Ad26 viral vectors: standardized template with key considerations for a risk/benefit assessment. Vaccine. 2020. https:// doi.org/10.1016/j.vaccine.2020.09.018.

87. "CanSinoBIO announces a supply agreement with Mexico on the advance purchase for COVID-19 vaccine". CanSino CanSino Biologics Inc., October 15, 2020, accessed January 26, 2021. http://www.cansinotech.com/html/1///179/180/ 556.html\#: : text=It \%20uses\%20the \%20replication \% 2D defective,easier\%20for \%20transportation \%20and\%20storage.

88. Dulal P, Wright D, Ashfield R, Hill AV, Charleston B, Warimwe GM. Potency of a thermostabilised chimpanzee adenovirus Rift Valley Fever vaccine in cattle. Vaccine. 2016;34(20):2296-8. https://doi.org/10.1016/ j.vaccine.2016.03.061.

89. Alcock R, Cottingham MG, Rollier CS, Furze J, De Costa SD, Hanlon $\mathrm{M}$, et al. Long-term thermostabilization of live poxviral and adenoviral vaccine vectors at supraphysiological temperatures in carbohydrate glass. Sci Transl Med. 2010;2(19):19ra2. doi: 10.1126/scitranslmed.3000490.

90. Simmons-Duffin S. "Why does Pfizer's COVID-19 vaccine need to be kept colder than Antarctica?". NPR, November 17, 2020, accessed December 9, 2020. https://www.npr.org/sections/ health-shots/2020/11/17/935563377/why-does-pfizers-covid-19vaccine-need-to-be-kept-colder-than-antarctica.

91. Demana PH, Davies NM, Hook S, Rades T. Quil A-lipid powder formulations releasing ISCOMs and related colloidal structures upon hydration. J Control Release. 2005;103(1):4559. https://doi.org/10.1016/j.jconrel.2004.11.027.

92. Li X, Thakkar SG, Ruwona TB, Williams RO 3rd, Cui Z. A method of lyophilizing vaccines containing aluminum salts into a dry powder without causing particle aggregation or decreasing the immunogenicity following reconstitution. J Control Release. 2015;204:38-50. https://doi.org/10.1016/ j.jconrel.2015.02.035.

93. "Pfizer and BioNTech conclude phase 3 study of COVID-19 vaccine candidate, meeting all primary efficacy endpoints." Pfizer Inc., November 18, 2020, accessed December 8, 2020, https://www.pfizer.com/news/press-release/press-release-detail/ pfizer-and-biontech-conclude-phase-3-study-covid-19-vaccine.

94. "Pfizer and BioNTech achieve first authorization in the world for a vaccine to combat COVID-19". Pfizer Inc., December 2, 2020, accessed December 8, 2020. https://www.pfizer.com/news/ press-release/press-release-detail/pfizer-and-biontech-achievefirst-authorization-world.

95. Roxby P. "When will you be eligible for the Covid vaccine?". BBC News, December 8, 2020, accessed December 9, 2020. https://www.bbc.com/news/health-55045639.

96. "Moderna's COVID-19 vaccine candidate meets its primary efficacy endpoint in the first interim analysis of the phase 3 COVE study". Moderna Inc., November 16, 2020, accessed December 9, 2020. https://investors.modernatx.com/newsreleases/news-release-details/modernas-covid-19-vaccine-candidate-meets-its-primary-efficacy.

97. "Centers for Disease Control and Prevention. Vaccine storage \& handling toolkit 2019 “. Centers of Disease Control and Prevention, January 2020. http://www.cdc.gov/vaccines/hcp/ admin/storage/toolkit/storage-handling-toolkit.pdf. Accessed 28 Sep 2020.

98. "Stability studies in a global environment". The World Health Organization, December, 2004, accessed December 17, 2020. https://www.who.int/medicines/services/expertcommittees/ pharmprep/QAS05_146Stabilitywithcomments.pdf.

99. Pelliccia M, Andreozzi P, Paulose J, D'Alicarnasso M, Cagno $\mathrm{V}$, Donalisio M, et al. Additives for vaccine storage to improve thermal stability of adenoviruses from hours to months. Nat Commun. 2016;7:13520. https://doi.org/10.1038/ncomms13520.

100. Ohtake S, Martin RA, Yee L, Chen D, Kristensen DD, Lechuga-Ballesteros D, et al. Heat-stable measles vaccine produced by spray drying. Vaccine. 2010;28(5):1275-84. https://doi.org/10.1016/j.vaccine.2009.11.024. 
101. Amorij JP, Meulenaar J, Hinrichs WL, Stegmann T, Huckriede $\mathrm{A}$, Coenen $\mathrm{F}$, et al. Rational design of an influenza subunit vaccine powder with sugar glass technology: preventing conformational changes of haemagglutinin during freezing and freeze-drying. Vaccine. 2007;25(35):6447-57. https:// doi.org/10.1016/j.vaccine.2007.06.054.

102. Ohtake S, Kita Y, Arakawa T. Interactions of formulation excipients with proteins in solution and in the dried state. Adv Drug Deliv Rev. 2011;63(13):1053-73. https://doi.org/10.1016/ j.addr.2011.06.011.

103. De Meyer L, Van Bockstal PJ, Corver J, Vervaet C, Remon JP, De Beer T. Evaluation of spin freezing versus conventional freezing as part of a continuous pharmaceutical freeze-drying concept for unit doses. Int J Pharm. 2015;496(1):75-85. https:// doi.org/10.1016/j.ijpharm.2015.05.025.

104. Leys L, Vanbillemont B, Van Bockstal PJ, Lammens J, Nuytten G, Corver J, et al. A primary drying model-based comparison of conventional batch freeze-drying to continuous spin-freeze-drying for unit doses. Eur J Pharm Biopharm. 2020;157:97-107. https://doi.org/10.1016/j.ejpb.2020.09.009.

105. Kastenmuller W, Gasteiger G, Stross L, Busch DH, Drexler I. Cutting edge: mucosal application of a lyophilized viral vector vaccine confers systemic and protective immunity toward intracellular pathogens. J Immunol. 2009;182(5):2573-7. https://doi.org/10.4049/jimmunol.0803871.

106. Heller MC, Carpenter JF, Randolph TW. Protein formulation and lyophilization cycle design: prevention of damage due to freeze-concentration induced phase separation. Biotechnol Bioeng. 1999;63(2):166-74. https://doi.org/10.1002/(sici)10970290(19990420)63:2<166::aid-bit5>3.0.co;2-h.

107. Heller MC, Carpenter JF, Randolph TW. Manipulation of lyophilization-induced phase separation: implications for pharmaceutical proteins. Biotechnol Prog. 1997;13(5):590-6. https:// doi.org/10.1021/bp970081b.

108. Randolph TW. Phase separation of excipients during lyophilization: effects on protein stability. J Pharm Sci. 1997;86(11):1198-203. https://doi.org/10.1021/js970135b.

109. Engstrom JD, Lai ES, Ludher BS, Chen B, Milner TE, Williams RO 3rd, et al. Formation of stable submicron protein particles by thin film freezing. Pharm Res. 2008;25(6):1334-46. https://doi.org/10.1007/s11095-008-9540-4.

110. Rexroad J, Wiethoff CM, Jones LS, Middaugh CR. Lyophilization and the thermostability of vaccines. Cell Preserv Technol. 2002;1(2):91-104.

111. Kanojia G, Have RT, Soema PC, Frijlink H, Amorij JP, Kersten G. Developments in the formulation and delivery of spray dried vaccines. Hum Vaccin Immunother. 2017;13(10):2364-78. https:// doi.org/10.1080/21645515.2017.1356952.

112. Saluja V, Amorij JP, Kapteyn JC, de Boer AH, Frijlink HW, Hinrichs WL. A comparison between spray drying and spray freeze drying to produce an influenza subunit vaccine powder for inhalation. J Control Release. 2010;144(2):127-33. https:// doi.org/10.1016/j.jconrel.2010.02.025.

113. Wong YL, Sampson S, Germishuizen WA, Goonesekera S, Caponetti G, Sadoff J, et al. Drying a tuberculosis vaccine without freezing. Proc Natl Acad Sci U S A. 2007;104(8):25915. https://doi.org/10.1073/pnas.0611430104.

114. Coucke D, Schotsaert M, Libert C, Pringels E, Vervaet C, Foreman P, et al. Spray-dried powders of starch and crosslinked poly(acrylic acid) as carriers for nasal delivery of inactivated influenza vaccine. Vaccine. 2009;27(8):1279-86. https://doi.org/10.1016/j.vaccine.2008.12.013.

115. Sou T, Meeusen EN, de Veer M, Morton DA, Kaminskas LM, McIntosh MP. New developments in dry powder pulmonary vaccine delivery. Trends Biotechnol. 2011;29(4):191-8. https:// doi.org/10.1016/j.tibtech.2010.12.009.

116. Sou T, Morton DA, Williamson M, Meeusen EN, Kaminskas LM, McIntosh MP. Spray-dried influenza antigen with trehalose and leucine produces an aerosolizable powder vaccine formulation that induces strong systemic and mucosal immunity after pulmonary administration. J Aerosol Med Pulm Drug Deliv. 2015;28(5):361-71. https://doi.org/10.1089/jamp.2014.1176.

117. Tonnis WF, Lexmond AJ, Frijlink HW, de Boer AH, Hinrichs WL. Devices and formulations for pulmonary vaccination.
Expert Opin Drug Deliv. 2013;10(10):1383-97. https://doi.org/ 10.1517/17425247.2013.810622.

118. Vishali DA, Monisha J, Sivakamasundari SK, Moses JA, Anandharamakrishnan C. Spray freeze drying: emerging applications in drug delivery. J Control Release. 2019;300:93101. https://doi.org/10.1016/j.jconrel.2019.02.044.

119. Maa YF, Ameri M, Shu C, Payne LG, Chen D. Influenza vaccine powder formulation development: spray-freeze-drying and stability evaluation. J Pharm Sci. 2004;93(7):1912-23. https://doi.org/10.1002/jps.20104.

120. Amorij JP, Saluja V, Petersen AH, Hinrichs WL, Huckriede A, Frijlink HW. Pulmonary delivery of an inulin-stabilized influenza subunit vaccine prepared by spray-freeze drying induces systemic, mucosal humoral as well as cell-mediated immune responses in BALB/c mice. Vaccine. 2007;25(52):8707-17. https://doi.org/10.1016/j.vaccine.2007.10.035.

121. Garmise RJ, Staats HF, Hickey AJ. Novel dry powder preparations of whole inactivated influenza virus for nasal vaccination. AAPS PharmSciTech. 2007;8(4):E81. https:// doi.org/10.1208/pt0804081.

122. Murugappan S, Patil HP, Kanojia G, ter Veer W, Meijerhof T, Frijlink HW, et al. Physical and immunogenic stability of spray freeze-dried influenza vaccine powder for pulmonary delivery: comparison of inulin, dextran, or a mixture of dextran and trehalose as protectants. Eur J Pharm Biopharm. 2013, 85(3 Pt A):716-25. https://doi.org/10.1016/j.ejpb.2013.07.018.

123. Maa YF, Zhao L, Payne LG, Chen D. Stabilization of alumadjuvanted vaccine dry powder formulations: mechanism and application. J Pharm Sci. 2003;92(2):319-32. https://doi.org/ 10.1002/jps.10294.

124. Qiu Y, Man RCH, Liao Q, Kung KLK, Chow MYT, Lam JKW. Effective mRNA pulmonary delivery by dry powder formulation of PEGylated synthetic KL4 peptide. J Control Release. 2019;314:102-15. https://doi.org/10.1016/j.jconrel.2019.10.026.

125. Yu Z, Johnston KP, Williams RO 3rd. Spray freezing into liquid versus spray-freeze drying: influence of atomization on protein aggregation and biological activity. Eur J Pharm Sci. 2006;27(1):9-18. https://doi.org/10.1016/j.ejps.2005.08.010.

126. Milani S, Faghihi H, Roulholamini Najafabadi A, Amini M, Montazeri H, Vatanara A. Hydroxypropyl beta cyclodextrin: a water-replacement agent or a surfactant upon spray freezedrying of $\mathrm{IgG}$ with enhanced stability and aerosolization. Drug Dev Ind Pharm. 2020;46(3):403-11. https://doi.org/10.1080/ 03639045.2020.1724131.

127. Lovalenti PM, Anderl J, Yee L, Nguyen V, Ghavami B, Ohtake S, et al. Stabilization of live attenuated influenza vaccines by freeze drying, spray drying, and foam drying. Pharm Res. 2016;33(5):1144-60. https://doi.org/10.1007/s11095-016-1860-1.

128. Overhoff KA, Johnston KP, Tam J, Engstrom J, Williams RO. Use of thin film freezing to enable drug delivery: a review. Drug Deliv Sci Technol. 2009;19(2):89-98. https://doi.org/ 10.1016/S1773-2247(09)50016-0.

129. AboulFotouh K, Zhang Y, Maniruzzaman M, Williams RO 3rd, Cui Z. Amorphous solid dispersion dry powder for pulmonary drug delivery: advantages and challenges. Int J Pharm. 2020;587:119711. https://doi.org/10.1016/j.ijpharm.2020.119711.

130. Sahakijpijarn S, Moon C, Ma X, Su Y, Koleng JJ, Dolocan A, et al. Using thin film freezing to minimize excipients in inhalable tacrolimus dry powder formulations. Int J Pharm. 2020:586:119490. https://doi.org/10.1016/j.ijpharm.2020.119490.

131. Beinborn NA, Du J, Wiederhold NP, Smyth HD, Williams RO 3rd. Dry powder insufflation of crystalline and amorphous voriconazole formulations produced by thin film freezing to mice. Eur J Pharm Biopharm. 2012;81(3):600-8. https://doi.org/ 10.1016/j.ejpb.2012.04.019.

132. Beinborn NA, Lirola HL, Williams RO 3rd. Effect of process variables on morphology and aerodynamic properties of voriconazole formulations produced by thin film freezing. Int J Pharm. 2012;429(1-2):46-57. https://doi.org/10.1016/ j.ijpharm.2012.03.010.

133. Carvalho SR, Watts AB, Peters JI, Liu S, Hengsawas S, Escotet-Espinoza MS, et al. Characterization and pharmacokinetic analysis of crystalline versus amorphous rapamycin dry powder via pulmonary administration in rats. Eur $\mathbf{J}$ Pharm 
Biopharm. 2014;88(1):136-47. https://doi.org/10.1016/ j.ejpb.2014.05.008.

134. Wang YB, Watts AB, Peters JI, Liu S, Batra A, Williams RO 3rd. In vitro and in vivo performance of dry powder inhalation formulations: comparison of particles prepared by thin film freezing and micronization. AAPS PharmSciTech. 2014;15(4):981-93. https://doi.org/10.1208/s12249-014-0126-7.

135. Watts AB, Wang YB, Johnston KP, Williams RO 3rd. Respirable low-density microparticles formed in situ from aerosolized brittle matrices. Pharm Res. 2013;30(3):813-25. https://doi.org/10.1007/s11095-012-0922-2.

136. Sahakijpijarn S, Moon C, Koleng JJ, Christensen DJ, Williams Iii RO. Development of remdesivir as a dry powder for inhalation by thin film freezing. Pharmaceutics. 2020;12(11). https://doi.org/10.3390/pharmaceutics12111002.

137. Alzhrani RF, Xu H, Moon C, Suggs LJ, Williams RO 3rd, Cui Z. Thin-film freeze-drying is a viable method to convert vaccines containing aluminum salts from liquid to dry powder. Methods Mol Biol. 2021;2183:489-98. https://doi.org/10.1007/ 978-1-0716-0795-4_27.

138. Thakkar SG, Ruwona TB, Williams RO 3rd, Cui Z. The immunogenicity of thin-film freeze-dried, aluminum saltadjuvanted vaccine when exposed to different temperatures. Hum Vaccin Immunother. 2017;13(4):936-46. https://doi.org/ 10.1080/21645515.2016.1259042.

139. Thakkar SG, Warnken ZN, Alzhrani RF, Valdes SA, Aldayel $\mathrm{AM}, \mathrm{Xu} \mathrm{H}$, et al. Intranasal immunization with aluminum saltadjuvanted dry powder vaccine. J Control Release. 2018;292:111-8. https://doi.org/10.1016/j.jconrel.2018.10.020.

140. Wang JL, Hanafy MS, Xu H, Leal J, Zhai Y, Ghosh D, et al. Aerosolizable siRNA-encapsulated solid lipid nanoparticles prepared by thin-film freeze-drying for potential pulmonary delivery. Int J Pharm. 2021;120215:120215. https://doi.org/ 10.1016/j.ijpharm.2021.120215.
141. "A phase I clinical trial of influenza virus vector COVID-19 vaccine for intranasal spray (DelNS1-2019-nCoV-RBDOPT1)". Chinese Clinical Trial Registry, September 8, 2019. http://www.chictr.org.cn/showprojen.aspx? proj=55421. Accessed 22 Oct 2020.

142. McKenzie H. "Could an intranasal COVID-19 vaccine be more efficient and effective than traditional approach?". October 5, 2020, https://www.biospace.com/article/why-an-intranasal-covid-19-vaccine-could-be-more-efficient-and-effective/.

143. Arthur R. "Needle-free COVID-19 vaccine COVI-VAC enters phase 1 trials". BioPharma-Reporter, January 11, 2021, accessed January 27, 2021. https://www.biopharma-reporter.com/Article/2021/01/11/Needle-free-COVID-19-vaccineCOVI-VAC-enters-Phase-1-trials.

144. Paltiel AD, Schwartz JL, Zheng A, Walensky RP. Clinical outcomes of a COVID-19 vaccine: implementation over efficacy. Health Aff (Millwood). 2020:101377hlthaff202002054. https://doi.org/10.1377/hlthaff.2020.02054.

145. Saey TH. "The 'last mile' for COVID-19 vaccines could be the biggest challenge yet". ScienceNews. December 3, 2020, accessed December 8, 2020, https://www.sciencenews.org/article/covid19-coronavirus-vaccine-last-mile-logistics-pfizermoderna.

146. "Development and licensure of vaccines to prevent COVID19". The US Food and Drug Administration, June 30, 2020, accessed December 8, 2020, https://www.fda.gov/media/139638/ download

Publisher's Note Springer Nature remains neutral with regard to jurisdictional claims in published maps and institutional affiliations. 